\title{
Performance of testers with different genetic structure for evaluation of maize inbred lines
}

\author{
Desempenho de testadores com diferentes estruturas genéticas para avaliação de linhagens \\ endogâmicas de milho
}

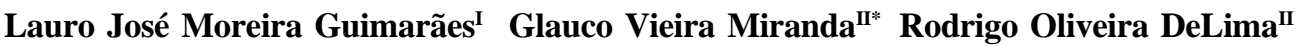 \\ Ciro MaiaII Lucimar Rodrigues de Oliveira" ${ }^{\text {II }}$ Leandro Vagno de Souza ${ }^{\text {III }}$
}

\begin{abstract}
The objective of this study was to evaluate four maize testers for identification of superior inbreed lines in testcross. The four testers evaluated are cultivars with narrow or wide genetic base (single-cross hybrids and open pollinated varieties) and two kernel types (flint or dent). SynD and SynF testers are open pollinated varieties with dent and flint kernels, respectively, and FSH and DSH testers are single-cross hybrids with flint and dent kernels, respectively. SynD tester showed the biggest genetic variance among the maize inbreed lines in crosses. The effects of general combining ability (GCA) for lines and specific combining ability (SCA) for lines $x$ testers were significant, whereas GCA effects for testers were not significant. SynD and SynF testers identified the largest number of lines with higher GCA. The DSH and FSH testers showed suitable to identify lines with high SCA. It was concluded that SynD and SynF testers are adequate to identify inbreed lines with high GCA effects, and it's possible to identify new lines with high heterotic potential in each one of the four testers.
\end{abstract}

Key words: Zea mays, diallel, testcross, combining ability.

\section{RESUMO}

O objetivo deste estudo foi avaliar quatro testadores de milho quanto à capacidade de identificar linhagens superiores em testcross. Os quatro testadores avaliados são cultivares com base genética ampla (variedades de polinização aberta) e estreita (híbridos simples) e dois tipos de grãos (duro e dentado). Os testadores SynD e SynF são populações de milho de polinização aberta com grãos dentados e duros, respectivamente, e FSH e DSH são híbridos simples com grãos duros e dentados, respectivamente. O testador SynD possibilitou a maior expressão de variância genética entre os cruzamentos com as linhagens. A capacidade geral de combinação (CGC) das linhagens e a capacidade específica de combinação (CEC) entre linhagens e testadores foram significativas, enquanto que os efeitos de CGC dos testadores foram não significativos. Concluiu-se que os testadores SynD e SynF mostram-se adequados para identificar linhagens com maiores efeitos de GCA e é possível identificar novas linhagens com alto potencial heterótico com cada um dos quatro testadores utilizados.

Palavras-chave: Zea mays, dialelo, testcross, capacidade de combinação.

\section{INTRODUCTION}

High maize yield can be obtained by crossing of two parents that show high heterosis in hybrid combinations (CARENA \& HALLAUER, 2001; GUIMARÃES et al., 2007; MIRANDA et al., 2008) and with the choice of adequate cultivars aiming to capitalize genotype $x$ environment interaction (FRITSCHE-NETO et al., 2010a; FALUBA et al., 2010).

The diallel matting can be used in maize breeding programs to identify parents with high favorable alleles frequencies and greater heterosis patterns in crosses (SILVA et al., 2003; PATERNIANI et al., 2008; CHAVES et al., 2008). Various methods of diallel analysis are used to determine genetic parameters of the parents, helping breeders to choice appropriated

${ }^{\mathrm{I} E m p r e s a}$ Brasileira de Pesquisa Agropecuária, Centro Nacional de Pesquisa de Milho e Sorgo (CNPMS), Sete Lagoas, MG, Brasil. "Departamento de Fitotecnia, Universidade Federal de Viçosa (UFV), 36570-000, Viçosa, MG, Brasil. E-mail: glaucovmiranda@ufv.br. *Autor para correspondência.

IIIDow Agrosciences Indústria Ltda, Ribeirão Preto, SP, Brasil. 
testers (MIRANDA FILHO \& VENCOVSKY, 1999; PFANN et al., 2009; OLIVEIRA et al., 2011).

In maize breeding programs is essential to select appropriate testers that correctly classify specific and general combining abilities (SCA and GCA) of inbred lines to produce hybrids with high yield potential for seed market exploitation, even for wide recommendation (DEITOS et al., 2006) or for specific environments such as soils with low availability of nitrogen (SOUZA et al., 2010), low phosphorus (FRITSCHE-NETO et al., 2010b) and aluminum toxicity (CANÇADO et al., 2002).

Testers have been used in maize breeding programs to form heterotic groups, assess the combining ability and to identify superior hybrid combinations. In addition, information about performance and combining ability of lines can be useful to further selection in early generations, with a good prediction of performance in advanced generations. GUTIÉRREZ-GAITAN et al. (1986), VASAL et al. (1992) and LI et al. (2007) emphasized the importance of testers; therefore, the success of a maize breeding program depends on the choice of the most appropriated testers to select superior lines with a significant reduction of costs and labor.

Ideal testers should allow great expression of genetic variability in their progeny (RUSSELL, 1961). Moreover, recessive homozygous lines and populations with low frequency of favorable alleles should be successful testers in plant breeding programs, because new lines with high frequency of favorable genes could be better identified by using that kind of testers (SMITH, 1986; HALLAUER et al., 2010).

On the other hand, the use of testers with a high frequency of favorable alleles allows identifying the best crossings, the ones with the highest specific combining ability with those testers. In this situation, the testers should be the best elite-lines of the breeding program, one of dent and other of flint heterotic groups, for example: the two parental lines of a good commercial hybrid (HALLAUER \& CARENA, 2009). So, new lines identified in superior crossings could become parents directly of commercial hybrids.

The objective of this study was to evaluate four testers with different genetic structures (single cross hybrids, with narrow genetic basis, and open pollinated varieties, with broad genetic basis) and different types of grains (flint and dent) for identification of superior inbreed lines in testcross.

\section{MATERIAL AND METHODS}

It was obtained 426 testcross hybrids, synthesized from crosses of four testers with a set of
162 inbred lines belonging to University Federal of Viçosa's maize breeding program, but only 45 lines were crossed with all the four testers. The testers used were: SynD and SynF, that are open-pollinated cultivars with dent and flint kernels, respectively, and FSH and DSH, that are single hybrids with flint and dent kernels, respectively.

A total of 441 treatments, comprising the 426 testcross hybrids and 15 checks, were evaluated in nine trials in $7 \times 7$ lattices with two replications. The experimental plot consisted of a row of four meters long with $0.90 \mathrm{~m}$ spacing between rows, which six seeds per meter for a population 65,000 plants per hectare. The following traits were evaluated: male flowering (MF), female flowering (FF), plant height ( $\mathrm{PH}, \mathrm{cm})$, final stand (ST) and grain yield (GY, $\left.\mathrm{kg} \mathrm{ha}^{-1}\right)$.

Preliminary analyses of variance were carried out for each experiment. The joint analysis of experiments was performed after to check the homogeneity of variance of all traits. It was also used a hierarchical statistic model to test the effects of different groups of genotypes. For this analysis, the sums squares of treatments were partitioned into the sum of squares of testcross, testers, lines within each tester, checks and contrast between testcross hybrids and the checks. A Scott-Knott test was performed for all 426 testcross hybrids to grouping genotypes according to means of grain yield, using a significance level of $1 \%$ of probability.

It was evaluated the testcross hybrids obtained from crosses between two groups of parents (testers - group 1 and lines - group 2). Therefore, 11 partial diallel analyses were carried out for all combinations of testers with lines in common. The genetic effects were determined by partial diallels according to methodology of GRIFFING (1956), adapted by GERALDI \& MIRANDA FILHO (1988). It was determined only for the trait grain yield. The genetic-statistic model used was: $\mathrm{y}_{\mathrm{ij}}=\mu+\mathrm{g}_{\mathrm{i}}+\mathrm{g}_{\mathrm{j}}+\mathrm{s}_{\mathrm{ij}}{ }^{-}{ }_{\mathrm{ij}}$, where: $\quad \mathrm{y}_{\mathrm{ij}}=$ mean of the hybrid combination between the $i^{\text {th }}$ parent of group 1 (testers) and $\mathrm{j}^{\text {th }}$ parent of group 2 (lines); $\mu=$ geral mean; $g_{i}=$ effect of general combining ability of the $i^{\text {th }}$ parent of group 1 (testers); $g_{j}=$ effect of general combining ability of the $\mathrm{j}^{\text {th }}$ parent of group 2(lines); $\mathrm{s}_{\mathrm{ij}}=$ effect of specific combining ability between the parents $\mathrm{i}$ and $\mathrm{j}$, of groups 1 and 2, respectively; ${ }^{-}=$random error associated with the mean ij.

\section{RESULTS AND DISCUSSION}

In the combined analysis of trials, it was found that the effects of treatments (testcross hybrids 
and checks) were significant for all traits that suggest the existence of genetic variability and the possibility of success in obtaining superior hybrids (Table 1 ). The general average for grain yield was $9524 \mathrm{~kg} \mathrm{ha}^{-1}$, and the best testcross hybrid yielded $13863 \mathrm{~kg} \mathrm{ha}^{-1}$. The group of 15 checks showed grain yield mean equal to $11367 \mathrm{~kg} \mathrm{ha}^{-1}$ and the 15 best testcross hybrids showed grain yield mean of $12730 \mathrm{~kg} \mathrm{ha}^{-1}$.

The effects of testers were not significant for GY and ST (Table 1). The effect of GY, MF, PH and ST were significant for inbred lines within each tester, indicating that the effects of lines were very important in the expression of genetic variability. These results also show that all testers allowed the expression of genetic variability since the lines were randomly sampled in their crosses which each tester.

The Scott-Knott test allowed the discrimination of three groups, among the 426 testcross hybrids, according to its grain yield mean. The first group was formed by the 326 best hybrids, which showed average grain yield ranging from 8560 to 13 $862 \mathrm{~kg} \mathrm{ha}^{-1}$, where the highest yield was achieved for the hybrid synthesized by crossing line 74 and DHS tester. The second group included 70 testcrosses hybrids with averages between 6369 and $8536 \mathrm{~kg} \mathrm{ha}^{-1}$, while the third group was formed by 30 testcross hybrids showing the worst performance in terms of grain yield, ranging from 1535 to $6193 \mathrm{~kg} \mathrm{ha}^{-1}$. Obviously, there is much more interest in new lines identified in the first group due to higher grain yield potential. So, these inbreed lines are the best candidates to became progenitors of commercial hybrids. Moreover, beyond those good crosses between testers and lines, these best lines should be crossed among them to test new hybrids with high potential to seed market exploitation. In table 2 are presented the parental lines that produced the 35 testcross hybrids with highest grain yield, selected among the 426 hybrids. The average of GY of these 35 hybrids was $12133 \mathrm{~kg}$ $\mathrm{ha}^{-1}$, and the top ten yielded $12868 \mathrm{~kg} \mathrm{ha}^{-1}$. The lines $74,117,53,24,122,56,49,34,113$ and 23 stood out as parents of the top ten testcrosses. So, these lines should be considered as good candidates to form single cross hybrids with high grain yield potential. Furthermore, among this group of 35 best testcross hybrids it can be seen the lines $24,122,56,113,23,26,40,4$ and 32, that were identified by the average of four testers as the most promising inbreed lines (Tables 2 and 3), with high estimates of GCA and SCA.

ELIAS et al. (2000) worked with open pollinated maize cultivars and found differences in absolute values for GCA, ranging from -56.05 to 90.30 , which differ in the frequency of favorable alleles for GY. DUARTE et al. (2003) found significant difference in the GCA for testers with high values, suggesting that the higher frequency of favorable alleles for improving the GY was in testers than lines. However, if a tester is used only to evaluate the combining abilities of lines, negative GCA estimate for this tester can be more interesting because the better expression of the favorable alleles from different lines depends on the frequency of unfavorable alleles form the testers (BARATA \& CARENA, 2006).

Table 1 - Analysis of variance for grain yield (GY, $\mathrm{kg} \mathrm{ha}^{-1}$ ), male flowering (MF, days), female flowering (FF, days), plant height (PH, $\mathrm{cm}$ ), and final stand (ST, plantas ha' ${ }^{-1}$ ).

\begin{tabular}{|c|c|c|c|c|c|c|}
\hline \multirow{2}{*}{ SV } & \multirow{2}{*}{$\mathrm{DF}$} & \multicolumn{5}{|c|}{ 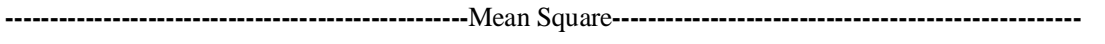 } \\
\hline & & GY & MF & FF & $\mathrm{PH}$ & ST \\
\hline Treatments & 440 & $7379516^{* *}$ & $3.026^{* *}$ & $2.623^{* *}$ & $409.8^{* *}$ & $295838227^{* *}$ \\
\hline Testcrosses & 425 & $7266333^{* *}$ & $3.020^{* *}$ & $2.621^{* *}$ & $403.5^{* *}$ & $292349562^{* *}$ \\
\hline Testers & 3 & $3337526^{\mathrm{ns}}$ & $45.953^{* *}$ & $51.487^{* *}$ & $2763.0^{* *}$ & $678809057^{\text {ns }}$ \\
\hline Lines/SynF & 121 & $6204683^{* *}$ & $3.052^{* *}$ & $2.541^{* *}$ & $297.1^{* *}$ & $278508681^{* *}$ \\
\hline Lines/SynD & 93 & $8457303^{* *}$ & $2.648^{* *}$ & $2.144^{* *}$ & $322.6^{* *}$ & $339083954^{* *}$ \\
\hline Lines/ FSH & 99 & $6498218^{* *}$ & $2.843^{* *}$ & $2.894^{* *}$ & $504.2^{* *}$ & $261402714^{* *}$ \\
\hline Lines/ DSH & 109 & $8234490^{* *}$ & $2.280^{* *}$ & $1.526^{\mathrm{ns}}$ & $434.5^{* *}$ & $285311101^{* *}$ \\
\hline Checks & 14 & $3813239^{\mathrm{ns}}$ & $3.390^{* *}$ & $2.857^{*}$ & $627.0^{* *}$ & $215232739^{\text {ns }}$ \\
\hline Top vs check & 1 & $105410202^{* *}$ & $0.618^{\text {ns }}$ & $0.064^{\mathrm{ns}}$ & $4.7^{\mathrm{ns}}$ & $2906997000^{* *}$ \\
\hline Error & 441 & 2905876 & 1.517 & 1.489 & 123.58 & 132445356 \\
\hline General mean & & 9524 & 60.73 & 60.95 & 232.28 & 59461 \\
\hline CV(\%) & & 17.9 & 2.03 & 2 & 4.79 & 19.35 \\
\hline
\end{tabular}

\footnotetext{
ns: not significant at $\mathrm{P}>0.05$ by $\mathrm{F}$ test; ${ }^{* * *}$ significant at $\mathrm{P}<0.05$ and $\mathrm{P}<0.01$, respectively, by $\mathrm{F}$ test.
} 
Table 2 - Ranking of grain yield (GY) for the 35 best hybrid among 426 testcross evaluated, and identification of their testers and parental lines, entry number and trial that they were selected, and this set of top 10 hybrid crosses.

\begin{tabular}{|c|c|c|c|c|c|}
\hline Ranking & Tester & Line & GY $\left(\mathrm{kg} \mathrm{ha}^{-1}\right)$ & Entry & Trial \\
\hline 1 & DHS & 74 & 13862 & 18 & 7 \\
\hline 2 & DHS & 117 & 13640 & 37 & 7 \\
\hline 3 & SynD & 53 & 13028 & 45 & 4 \\
\hline 4 & DHS & $24^{*}$ & 12919 & 9 & 6 \\
\hline 5 & FHS & $122^{*}$ & 12821 & 45 & 5 \\
\hline 6 & SynD & $56^{*}$ & 12762 & 24 & 9 \\
\hline 7 & DHS & 49 & 12731 & 39 & 8 \\
\hline 8 & FHS & 34 & 12701 & 45 & 8 \\
\hline 9 & SynD & $113^{*}$ & 12607 & 8 & 4 \\
\hline 10 & FHS & $23^{*}$ & 12604 & 8 & 5 \\
\hline 11 & SynF & 133 & 12422 & 13 & 4 \\
\hline 12 & FHS & 48 & 12299 & 24 & 5 \\
\hline 13 & FHS & 11 & 12271 & 37 & 9 \\
\hline 14 & DHS & $26^{*}$ & 12217 & 11 & 6 \\
\hline 15 & FHS & 25 & 12062 & 10 & 5 \\
\hline 16 & FHS & 42 & 12061 & 20 & 5 \\
\hline 17 & DHS & 92 & 11989 & 4 & 7 \\
\hline 18 & FHS & 83 & 11984 & 12 & 8 \\
\hline 19 & DHS & 31 & 11964 & 25 & 8 \\
\hline 20 & DHS & 116 & 11889 & 14 & 7 \\
\hline 21 & SynF & 52 & 11881 & 23 & 1 \\
\hline 22 & FHS & 120 & 11857 & 46 & 8 \\
\hline 23 & SynF & $40^{*}$ & 11784 & 17 & 1 \\
\hline 24 & DHS & $4^{*}$ & 11781 & 1 & 6 \\
\hline 25 & SynD & 99 & 11766 & 14 & 4 \\
\hline 26 & SynF & $32^{*}$ & 11640 & 15 & 1 \\
\hline 27 & DHS & 6 & 11605 & 3 & 6 \\
\hline 28 & SynD & 19 & 11549 & 46 & 3 \\
\hline 29 & DHS & 98 & 11514 & 1 & 7 \\
\hline 30 & SynF & 119 & 11489 & 28 & 3 \\
\hline 31 & SynD & 63 & 11462 & 27 & 2 \\
\hline 32 & SynD & 156 & 11418 & 11 & 9 \\
\hline 33 & SynF & 22 & 11392 & 5 & 3 \\
\hline 34 & DHS & 121 & 11383 & 44 & 6 \\
\hline 35 & SynD & 110 & 11280 & 9 & 2 \\
\hline
\end{tabular}

${ }^{*}$ Elite lines identified as superior in the partial diallel analysis with all four testers.

These results from the partial diallel involving the four testers and the same 45 inbred lines showed no significant effect for testers' GCA $(\mathrm{P}>0.05)$ and significant $(\mathrm{P}<0.01)$ for $\mathrm{GCA}$ for lines and for tester $\mathrm{x}$ lines SCA. It means that additive and non-additive genetic effects (dominance and epitasis) were important in this genetic pool and that the lines have different performances according to the tester used. Thus, different lines can be selected according to the tester and promising hybrids can be synthesized crossing lines with complementary genetic pools, allowing best exploitation of heterosis, as suggested by HALLAUER et al. (2010).
Similarly, to the diallel analysis performed for the 11 groups of crossings of lines by testers, it was only found significance to GCA for lines and to SCA for hybrid combinations. Although there were no significance to GCA for testers, FSH showed positive estimates in all seven partial diallel involved, with estimates ranging from 65.3 to 284.6 . On the other hand, each one of the two dent testers showed only one positive, but of low magnitude, estimate for GCA (10.6 for SynD, and 82.8 for DHS), while de other six estimates were negative, ranging from -39.8 to -155.6 for $\mathrm{SynD}$, and from -10.6 to -165.9 for DHS. It indicates that these dent testers have low frequency of favorable alleles 
Table 3 - Classification of grain yield (GY, $\left.\mathrm{kg} \mathrm{ha}^{-1}\right)$ for 45 maize lines for each tester, and mean testers.

\begin{tabular}{|c|c|c|c|c|c|c|c|c|c|c|}
\hline \multirow{2}{*}{ Rank } & \multicolumn{2}{|c|}{-----------SynF-----------. } & \multicolumn{2}{|c|}{----------SynD----------- } & \multicolumn{2}{|c|}{-----------FSH-----------. } & \multicolumn{2}{|c|}{----------DSH------------ } & \multicolumn{2}{|c|}{----Mean Testers------- } \\
\hline & Line & GY & Line & GY & Line & GY & Line & GY & Line & GY \\
\hline 1 & 52 & 11859 & $56^{*}$ & 12878 & $122^{*}$ & 12822 & $24^{*}$ & 12919 & 4 & 11061 \\
\hline 2 & $40^{*}$ & 11780 & $113^{*}$ & 12608 & $23^{*}$ & 12604 & $26^{*}$ & 12218 & 24 & 10830 \\
\hline 3 & $32^{*}$ & 11643 & $122^{*}$ & 11984 & 48 & 12299 & $4^{*}$ & 11782 & 45 & 10827 \\
\hline 4 & 159 & 11382 & 63 & 11970 & 42 & 12061 & 121 & 11383 & 26 & 10810 \\
\hline 5 & $56^{*}$ & 11366 & $26^{*}$ & 11714 & 120 & 11857 & $32^{*}$ & 11201 & 23 & 10797 \\
\hline 6 & $24^{*}$ & 11228 & $23^{*}$ & 11673 & 55 & 11830 & 131 & 11197 & 122 & 10693 \\
\hline 7 & $45^{*}$ & 10940 & 156 & 11346 & $4^{*}$ & 11699 & 29 & 11110 & 32 & 10691 \\
\hline 8 & $4^{*}$ & 10473 & $40^{*}$ & 11095 & 63 & 11560 & 52 & 11031 & 56 & 10656 \\
\hline 9 & 13 & 10451 & 104 & 11027 & 129 & 11043 & 120 & 10937 & 40 & 10353 \\
\hline 10 & $26^{*}$ & 10309 & 148 & 10799 & 84 & 11013 & 104 & 10904 & 113 & 10352 \\
\hline 11 & 121 & 10204 & 105 & 10798 & 29 & 10783 & $45^{*}$ & 10904 & 52 & 10329 \\
\hline 12 & 29 & 10156 & $45^{*}$ & 10766 & 13 & 10713 & 112 & 10780 & 63 & 10320 \\
\hline 13 & 161 & 9976 & 52 & 10390 & $45^{*}$ & 10697 & 125 & 10780 & 121 & 10227 \\
\hline 14 & 120 & 9952 & $4^{*}$ & 10290 & 57 & 10541 & $113^{*}$ & 10751 & 29 & 10024 \\
\hline 15 & 63 & 9910 & 41 & 10222 & 14 & 10535 & 57 & 10420 & 57 & 9975 \\
\hline 16 & $122^{*}$ & 9882 & 142 & 10100 & 17 & 10521 & 33 & 10159 & 104 & 9944 \\
\hline 17 & 14 & 9671 & $24^{*}$ & 9918 & 106 & 10491 & 42 & 9990 & 131 & 9841 \\
\hline 18 & 104 & 9634 & 139 & 9762 & 41 & 10305 & 44 & 9957 & 105 & 9744 \\
\hline 19 & $23^{*}$ & 9612 & $32^{*}$ & 9750 & 131 & 10266 & 148 & 9687 & 55 & 9620 \\
\hline 20 & 48 & 9562 & 121 & 9714 & $32^{*}$ & 10170 & 14 & 9682 & 14 & 9608 \\
\hline 21 & 150 & 9535 & 125 & 9566 & 107 & 9841 & 55 & 9584 & 125 & 9490 \\
\hline 22 & 57 & 9525 & 57 & 9413 & 105 & 9645 & 41 & 9520 & 148 & 9416 \\
\hline 23 & 125 & 9370 & 130 & 9402 & 121 & 9607 & 160 & 9440 & 48 & 9342 \\
\hline 24 & 105 & 9327 & 42 & 9234 & 148 & 9512 & $23^{*}$ & 9298 & 33 & 9334 \\
\hline 25 & 138 & 9275 & 138 & 9175 & 138 & 9509 & 105 & 9206 & 129 & 9280 \\
\hline 26 & 142 & 9239 & 129 & 9122 & $56^{*}$ & 9438 & 129 & 9197 & 42 & 9278 \\
\hline 27 & 131 & 9220 & 154 & 9087 & $40^{*}$ & 9408 & $40^{*}$ & 9129 & 13 & 9258 \\
\hline 28 & 17 & 9074 & 33 & 9056 & $113^{*}$ & 9392 & 154 & 9099 & 120 & 9217 \\
\hline 29 & 55 & 8962 & 17 & 8771 & 161 & 9383 & 161 & 9028 & 17 & 9198 \\
\hline 30 & 33 & 8777 & 131 & 8682 & 33 & 9342 & $56^{*}$ & 8944 & 41 & 8911 \\
\hline 31 & 44 & 8720 & 14 & 8543 & $24^{*}$ & 9256 & 84 & 8596 & 161 & 8905 \\
\hline 32 & $113^{*}$ & 8657 & 48 & 8388 & $26^{*}$ & 9002 & 107 & 8573 & 156 & 8773 \\
\hline 33 & 107 & 8618 & 13 & 8321 & 160 & 8508 & 17 & 8425 & 112 & 8727 \\
\hline 34 & 112 & 8536 & 55 & 8103 & 139 & 8330 & 156 & 8172 & 107 & 8624 \\
\hline 35 & 84 & 8494 & 29 & 8047 & 125 & 8244 & 106 & 8091 & 139 & 8363 \\
\hline 36 & 139 & 8306 & 160 & 8010 & 104 & 8212 & $122^{*}$ & 8083 & 106 & 8342 \\
\hline 37 & 106 & 8171 & 112 & 7601 & 142 & 8161 & 63 & 7841 & 138 & 8270 \\
\hline 38 & 156 & 7841 & 107 & 7463 & 150 & 8077 & 13 & 7549 & 84 & 8229 \\
\hline 39 & 129 & 7756 & 161 & 7233 & 52 & 8038 & 48 & 7117 & 160 & 8201 \\
\hline 40 & 148 & 7666 & 44 & 7115 & 112 & 7991 & 159 & 7108 & 142 & 7889 \\
\hline 41 & 154 & 7212 & 106 & 6616 & 130 & 7783 & 139 & 7053 & 154 & 7457 \\
\hline 42 & 160 & 6848 & 150 & 5648 & 156 & 7733 & 150 & 6351 & 150 & 7403 \\
\hline 43 & 42 & 5828 & 84 & 4815 & 159 & 6892 & 130 & 5926 & 159 & 7388 \\
\hline 44 & 41 & 5599 & 159 & 4171 & 154 & 4432 & 138 & 5120 & 44 & 7380 \\
\hline 45 & 130 & 4097 & 120 & 4120 & 44 & 3727 & 142 & 4055 & 130 & 6802 \\
\hline \multicolumn{2}{|c|}{ Mean } & \multicolumn{2}{|l|}{9214} & \multicolumn{2}{|l|}{9211} & \multicolumn{2}{|l|}{9628} & \multicolumn{2}{|l|}{9295} & 9337 \\
\hline \multicolumn{2}{|c|}{ Top 15 Mean } & \multicolumn{2}{|l|}{11143} & \multicolumn{2}{|l|}{11709} & \multicolumn{2}{|l|}{11878} & \multicolumn{2}{|l|}{11468} & 10707 \\
\hline \multicolumn{2}{|c|}{ Variance } & \multicolumn{2}{|c|}{2631538} & \multicolumn{2}{|c|}{4269822} & 35 & & 35 & & 1236909 \\
\hline
\end{tabular}

* Lines classified like the 10 highest producers for four testers. 
for GY in comparison with FSH. SynF tester showed three positive estimates for CGA (from 7.1 to 117.5 ) and four negative estimates (from -65.3 to -103.9). Therefore, hybrids with different heterosis patterns can be formed when lines are selected by testers with divergent estimates of GCA and less agreement in ranking the lines. SynD tester showed the greatest genetic variance for testcrosses among the four testers (Table 3), and the same trend occurred for lines/tester mean square estimates (Table 1). For these reasons and also for its negative GCA estimates, SynD is probably the best tester to discriminate these groups of inbreed lines. Furthermore, this tester showed greater concordance in ranking the top lines with average of the four testers, because among its 15 best testcross, eight of those lines were also higher in the general classification for all testers (Table 3). SynF was able to select seven of the best lines in the upper 15 testcross ranked by all testers, while DSH and FSH, selected six and four lines, respectively. Only two lines were selected in common by SynD and SynF, and this could be a consequence of the different types of grain between SynD and SynF, that are traditionally referred as divergent and complementary heterotic groups. So, it can be inferred that this pair of testers can be used to select lines, assessing genotypes with high general combining ability and, simultaneously, arranging them in complementary heterotic groups.

The correlation of ranking between the lines classification by different testers were of low magnitude, ranging from 0.29 (FHS and DHS) to -0.13 (SynD and FHS), but some lines showed superior performance with all the testers (Table 3). Lines 4 and 26 , for example, were among the top ten testcross hybrids to three testers and lines 23, 24, 122, 32 and 40 for two testers. This shows that these lines have good general combining ability and, probably, all non-related testers should be able to identify them. Furthermore, it was possible to identify lines that had high SCA estimates with each tester used. The high genetic variability observed in the testcross hybrids, the low frequency of favorable alleles and the high concordance in lines classification with the average of other testers are desirable characteristics for a good maize tester. Therefore, SynD was better suited to inbreed line selection with high frequency of favorable alleles, and SynF can be usefull as a complement tester with SynD, to arrange selected lines in two heterotic group.

\section{CONCLUSION}

It was concluded that SynD and SynF testers are adequate to identify inbreed lines with high
GCA effects and arrange selected lines in two heterotic groups in the maize breeding program, and it's possible to identify new lines with high heterotic potential in each one of the four testers.

\section{ACKNOWLEGMENTS}

We thank the Foundation for Research Support of Minas Gerais State (Fapemig), the Brazilian Federal Agency for Support and Evaluation of Graduate Education (Capes), and the National Council for Scientific and Technological Development $(\mathrm{CNPq})$ for financial support.

\section{REFERENCES}

BARATA, C.; CARENA, M.J. Classification of North Dakota maize inbred lines into heterotic groups based on molecular and test cross data. Euphytica, v.151, p.339-349, 2006. Available from: $\quad<$ http://www.springerlink.com/content/ x463408u12275h27/fulltext.pdf $>$. Accessed: Nov. 16, 2010. doi: $10.1007 / \mathrm{s} 10681-006-9155-\mathrm{y}$.

CANÇADO, G.M.A. et al. Avaliação de nove linhagens de milho em cruzamentos dialélicos quanto à tolerância ao alumínio. Pesquisa Agropecuária Brasileira, v.37, 471-478, 2002. Available from: <http://www.scielo.br/pdf/pab/v37n4/ 9079.pdf>. Accessed: Nov. 13, 2010. doi: 10.1509/S0100$204 \times 2002000400007$.

CARENA, M.J.; HALlAUER, A. Expression of heterosis in leaming and midland yellow dent maize populations. Journal Iowa Academy Science, v.108, p.73-78, 2001.

CHAVES, L.G. et al. Parental commercial maize for silage production. Revista Brasileira de Milho e Sorgo, v.7, p.183-194, 2008. Available from: <http:// rbms.cnpms.embrapa.br/index.php/ojs/article/viewFile/264/ 273>. Accessed: Jul. 10, 2010.

DEITOS, A. et al. Yield and combining ability of maize cultivars under different ecogeographic conditions. Crop Breeding and Applied Biotechnology, v.6, p.222-227, 2006. Available from: <http://www.sbmp.org.br/cbab/siscbab/uploads/bd6ba09c5395-d48d.pdf>. Accessed: Dec. 11, 2010.

DUARTE, I.A. et al. Potencial discriminatório de três testadores em "testcross" de milho. Pesquisa Agropecuária Brasileira, v.38, p.365-372, 2003. Available from: <http://www.scielo.br/ pdf/pab/v38n3/v38n3a05.pdf $>$. Accessed: Nov. 13, 2010. doi: 10.1509/S0100-204X2003000300005.

ELIAS, H.T. et al. Comparação de testadores na avaliação de famílias S2 de milho. Pesquisa Agropecuária Brasileira, v.35, p.1135-1142, 2000. Available from: <http://www.scielo.br/ pdf/pab/v35n6/4668.pdf>. Accessed: Nov. 13, 2010. doi: 10.1509/S0100-204X2000000600009.

FALUBA, J.S. et al. Potencial genético da população de milho UFV 7 para o melhoramento em Minas Gerais. Ciência Rural, v.40, p.1250-1256, 2010. Available from: <http://www.scielo.br/ pdf/cr/v40n6/a631cr2691.pdf>. Accessed: Dec. 10, 2010. doi: 10.1590/S0103-84782010000600002. 
FRITSCHE-NETO, R. et al. Herança de caracteres associados à eficiência de utilização do fósforo em milho. Pesquisa Agropecuária Brasileira, v.45, p.465-471, 2010a. Available from: <http://www.scielo.br/pdf/pab/v45n5/05.pdf >. Accessed: Nov. 28, 2010. doi: 10.1509/S0100-204X2010000500005.

FRITSCHE-NETO, R. et al. Factor analysis and SREG GGE biplot for the genotype $\times$ environment interaction stratification in maize. Ciência Rural, v.40, p.1043-1048, 2010b. Available from: <http://www.scielo.br/pdf/cr/v40n5/a576cr2396.pdf $>$. Accessed: Aug. 5, 2010. doi: 10.1590/S010384782010000500007 .

GERALDI, I.O.; MIRANDA FILHO, J.B. Adapted models for the analysis of combining ability of varieties in partial crosses. Revista Brasileira de Genética, v.11, p.419-430, 1988.

GRIFFING, B. Concept of general and specific combining ability in relation to diallel crossing systems. Australian Journal of Biological Sciences, v.9, p.463-493, 1956.

GUIMARÃES, P.S. et al. Correlação da heterose de híbridos de milho com divergência genética entre linhagens. Pesquisa Agropecuária Brasileira, v.42, p.811-816, 2007. Available from: <http://www.scielo.br/pdf/pab/v42n6/v42n6a07.pdf>. Accessed: Nov. 28, 2010. doi: 10.1509/S0100-204X20070006.

GUTIERREZ-GAITAN, M.A. et al. Testcross evaluation of Mexican maize populations. Crop Science, v.26, p.99-104, 1986.

HAllaUER, A.; CARENA, M.J. Maize breeding. In: CARENA, M.J. Handbook of plant breeding: cereals. New York: Springer, 2009. p.3-98.

HALLAUER, A.R. et al. Quantitative genetics in maize breeding. 2.ed. Ames: Iowa State University, 2010. 468p.

LI, M.S. et al. Comparisons of four testers in evaluating 27 CIMMYT and Chinese maize populations. Maydica, v.52, p.173-179, 2007. Available from: < http://www.maydica.org/ articles/52_173.pdf>. Accessed: Nov. 28, 2010.

MIRANDA FILHO, J.B.; VENCOVSKY, R. The partial circulant diallel cross at the interpopulation level. Genetics and Molecular Biology, v.22, p.249-255, 1999. Available from: $<$ http://www.scielo.br/pdf/gmb/v22n2/0291.pdf $>$. Accessed: Nov. 23, 2010. doi: 10.1590/S1415-47571999000200020.
MIRANDA, G.V. et al. Genetic variability and heterotic groups of Brazilian popcorn populations. Euphytica, v.162, p.431440, 2008. Available from: <http://www.springerlink.com/ content/k912m750t0t17r1n/fulltext.pdf $>$. Accessed: Nov. 29, 2010. doi: 10.1007/s10681-007-9598-9.

OLIVEIRA, L.R. et al. Combining ability of tropical maize cultivars in organic and conventional production systems. Ciência Rural, v.41, p.739-745, 2011. Available from: <http:/ /www.scielo.br/pdf/cr/v41n5/a937cr4128.pdf>. Accessed: Oct. 10, 2011. doi: 10.1590/S0103-84782011000500001.

PATERNIANI, M.E.A.G.Z. et al. Capacidade combinatória, divergência genética entre linhagens de milho e correlação com heterose. Bragantia, v.67, p.639-648, 2008. Available from: $<$ http://www.scielo.br/pdf/brag/v67n3/a12v67n3.pdf $>$. Accessed: Jan. 13, 2011. doi: 10.1590/S000687052008000300012 .

PFANN, A.Z. et al. Capacidade combinatória entre híbridos simples de milho em dialelo circulante. Ciência Rural, v.39, p.635-64, 2009. Available from: <http://www.scielo.br/pdf/cr/ v39n3/a02v39n3.pdf>. Accessed: Jan. 12, 2011. doi: 10.1590/ S0103-84782009000300002.

RUSSELL, W.A. A comparison of five types of testers in evaluating the relationship of stalk rot in corn inbreed lines and stalk strength of the lines in hybrids combinations. Crop Science, v.1, p.393-397, 1961.

SILVA, R.G. et al. Controle genético da resistência aos enfezamentos em milho. Pesquisa Agropecuária Brasileira, v.38, p.921-928, 2003. Available from: <http://www.scielo.br/ pdf/pab/v38n8/18232.pdf $>$. Accessed: Oct. 8, 2010. doi: 10.1590/S0100-204X2003000800004.

SOUZA, L.V. et al. Inter-relações de nitrogênio e fósforo na capacidade de combinação e na seleção de milho. Revista Ceres, v.57, p.633-641, 2010. Available from: <http:// www.ceres.ufv.br/ceres/revistas/V57N005P11108.pdf $>$. Accessed: Nov. 8, 2010.

SMITH, O.S. Covariance between line per se and testcross performance. Crop Science, v.26, p.540-543, 1986.

VASAL, S.K. et al. Heterotic patterns of ninety-two white tropical CIMMYT Maize lines. Maydica, v.37, p.259-270, 1992. 